\title{
PROSPEK PENINGKATAN KUALITAS KOMPONEN PARIWISATA DI KERATON SURAKARTA
}

\author{
Devi Rusdiana Putri ${ }^{1}$, Agam Marsoyo ${ }^{2}$ \\ ${ }^{1}$ Email : devirusdianaputri@gmail.com \\ Magister Arsitektur dan Perencanaan Pariwisata, Universitas Gajah Mada \\ 2Email : agam@ugm.ac.id \\ Departemen Teknik Arsitektur dan Perencanaan, Universitas Gajah Mada
}

\begin{abstract}
Surakarta and Yogyakarta Palace are two palaces that historically connected and both are located in the middle of Surakarta dan Yogyakarta region. They offer nearly the same tourist products, but they have significantly different tourist numbers. Whereas, Surakarta Palace itself has various potential tourist attractions to visit. This study aimed to measure quality and define the prospect of tourism component development in Surakarta Palace. This research used questionnaire with random sampling technique which later supported by observation and interview to the parties concerned. This study found out that : (1) the tourism component quality in Surakarta palace is different compared to Yogyakarta palace due the lack of diversity in attractions and limited amenities choices. (2) But Surakarta Palace has wide range of potential that can be well-developed. (3) The support from local government and community have not enough yet to encourage the improvement of tourism component's quality in Surakarta Palace.
\end{abstract}

Abstrak: Surakarta dan Keraton Yogyakarta adalah dua istana yang terhubung secara historis dan keduanya terletak di tengah-tengah wilayah Surakarta dan Yogyakarta. Surakarta dan Yogyakarta menawarkan produk wisata yang hampir sama, tetapi memiliki jumlah wisatawan yang sangat berbeda. Istana Surakarta sendiri memiliki berbagai tempat wisata potensial untuk dikunjungi. Penelitian ini bertujuan untuk mengukur kualitas dan menentukan prospek pengembangan komponen pariwisata di Keraton Surakarta. Penelitian ini menggunakan kuesioner dengan teknik random sampling yang kemudian didukung oleh observasi dan wawancara kepada pihak-pihak terkait. Studi ini menemukan bahwa: (1) kualitas komponen wisata di istana Surakarta berbeda dibandingkan dengan istana Yogyakarta karena kurangnya keragaman dalam atraksi dan pilihan fasilitas yang terbatas. (2) namun Keraton Surakarta memiliki berbagai potensi yang dapat dikembangkan dengan baik. (3) dukungan dari pemerintah dan masyarakat setempat belum cukup untuk mendorong peningkatan kualitas komponen pariwisata di Keraton Surakarta.

Keywords: surakarta palace, stakeholders, quality of tourism. 


\section{PENDAHULUAN}

Keraton Surakarta dan Keraton Yogyakarta merupakan daya tarik utama bagi kepariwisataan Kota Surakarta dan Kota Yogyakarta. Pada rentang tahun 2012-2016, jumlah wisatawan yang berkunjung ke Keraton Surakarta adalah 296.533 wisatawan dengan rincian 8.265 wisatawan mancanegara dan 288.268 wisatawan nusantara (Badan Pusat Statistik Kota Surakarta Tahun 20122016). Sedangkan jumlah wisatawan yang berkunjung ke Keraton Yogyakarta adalah sebanyak 3.470.299 wisatawan, dengan rincian 496.803 wisatawan mancanegara dan 2.973.466 wisatawan nusantara pada rentang waktu yang sama (Dinas Pariwisata DIY, 2016). Adanya ketimpangan jumlah wisatawan di Keraton Surakarta dan Keraton Yogyakarta menjadi menarik, mengingat keduanya menawarkan jenis produk wisata yang sama, yaitu wisata sejarah. Selain itu, akses menuju kawasan Keraton Surakarta terbilang cukup mudah karena lokasinya yang berada di pusat keramaian Kota Surakarta.

Dualisme kekuasaan yang terjadi semenjak meninggalnya PB XII menyebabkan pengelola belum banyak melakukan intervensi terhadap kegiatan pariwisata di keraton. Sehingga dampak dari kegiatan wisata di Keraton Surakarta belum berpengaruh langsung untuk masyarakat sekitar. Berdasarkan observasi awal peneliti, banyak wisatawan yang tertarik untuk berkunjung meskipun pengelola hanya mengandalkan museum sebagai daya tarik utama. Selain itu, saat ini, dukungan pemerintah Kota Surakarta, komunitas dan masyarakat setempat begitu besar dengan terselenggaranya kegiatankegiatan yang bertujuan untuk menggali potensi wisata guna menambah keragaman aktivitas wisatawan ketika berkunjung ke Keraton Surakarta.

Penelitian ini dilakukan bertujuan untuk menjelaskan seberapa besar prospek pengembangan pariwisata Keraton Surakarta mengingat perannya sebagai salah satu destinasi unggulan di Kota Surakarta melalui komponen utama pariwisata. Menurut Cooper (1998), komponen pariwisata terbagi menjadi atraksi (attraction), amenitas (amenities), akses (access) dan fasilitas tambahan (ancillary services), salah satunya adalah lembaga kepariwisataan. Saat ini, komponenkomponen pariwisata tersebut belum bersinergi dan terintegrasi dengan baik di
Keraton Surakarta.Tung dan Ritchie (2011) mengatakan bahwa atraksi harus dikelola untuk menunjang kenyamanan dan memberikan kebermanfaatan bagi wisatawan saat berkunjung. Sehingga lembaga pariwisata bertanggungjawab untuk merencanakan dan mengembangkan destinasi wisata, serta memfasilitasi segala kebutuhan pengembangan destinasi guna membentuk pengalaman yang berkesan bagi wisatawan.

Kesan dan kepuasan wisatawan dapat diketahui melalui interaksi yang terjadi antara wisatawan dengan destinasi. Kepuasan wisatawan akan sebuah destinasi akan menciptakan hubungan keterikatan antara wisatawan dengan destinasi, sehingga wisatawan akan melakukan kunjungan kembali dan kemudian merekomendasikan kunjungan tersebut kepada kerabat (Chi, 2012). Sehingga, dalam penelitian ini, prospek didefinisikan sebagai probabilitas yang terbentuk akan peningkatan kualitas komponen wisata pada suatu destinasi berdasarkan kemampuan dari daya dukung destinasi tersebut. Maka dari itu, penentuan prospek pada penelitian dipengaruhi oleh nilai kualitas (kemampuan) komponen wisata yang didukung dengan keberadaan potensi-potensi wisata yang ada.

\section{METODE}

Penelitian ini adalah penelitian deskriptif kualitatif dengan cara berfikir deduktif. Dalam penelitian ini, mula-mula peneliti menentukan variabel penelitian dari teori-teori terkait. Tujuan dari penelitian ini adalah untuk mengukur kualitas serta menentukan prospek peningkatan kualitas komponen pariwisata Keraton Surakarta. Untuk itu, peneliti mengumpulkan berbagai teori mengenai komponen pariwisata dan prospek peningkatan kualitas pariwisata.

Kemudian, peneliti mengumpulkan data melalui proses kajian, wawancara, observasi dan penyebaran kuesioner di Keraton Yogyakarta dan Surakarta. Selanjutnya peneliti membandingkan serta menganalisis kualitas komponen pariwisata di Keraton Surakarta berdasarkan indikator dan kondisi kepariwisataan di Keraton Yogyakarta. Langkah terakhir yang dilakukan peneliti adalah melakukan penarikan kesimpulan sebagai dasar untuk menentukan prospek dari 
pengembangan kegiatan wisata di Keraton Surakarta.

\section{HASIL DAN PEMBAHASAN}

Berdasarkan kondisi kepariwisataan di Keraton Yogyakarta dan indikator yang dikeluarkan oleh Dirjen Pengembangan Destinasi Pariwisata Departemen Kebudayaan dan Pariwisata (2009), berikut temuan dari penilaian kualitas komponen pariwisata di keraton Surakarta:

\section{Atraksi}

Keragaman atraksi wisata di Keraton Surakarta tidak beragam dan terbatas (Gambar 1). Informasi yang tersedia di area museum banyak yang mulai tidak terbaca karena pengelola tidak melakukan intervensi terhadap kegiatan wisata di Keraton Surakarta (Gambar 2). Meskipun wisatawan mengatakan kunjungannya bermanfaat, wisatawan mengeluhkan tata kelola ruang museum yang dirasa kurang menarik dan cenderung membosankan. Namun, wisatawan menilai pelayanan pengelola dan mobilitas wisatawan di Keraton Surakarta baik serta mudah.

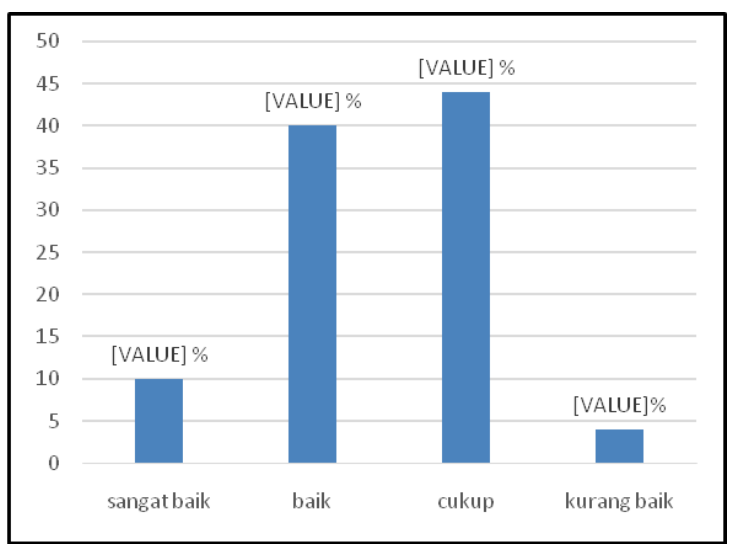

Gambar 1. Tingkat Keragaman Atraksi Wisata di Keraton Surakarta

Sumber : Survey Kuesioner Peneliti, 2018.

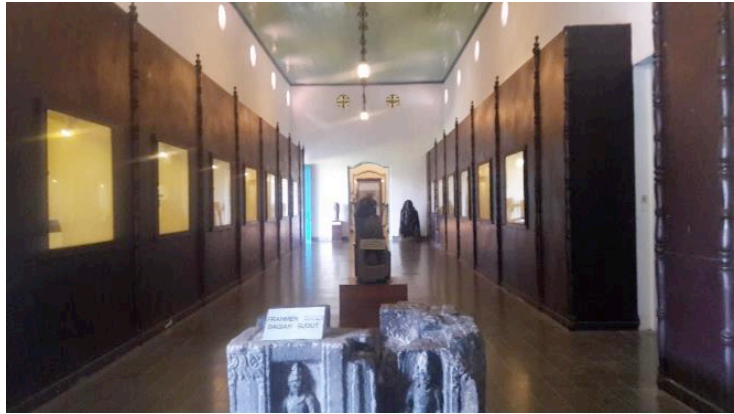

Gambar 2. Kondisi Museum Keraton Surakarta

Sumber : Dokumentasi Pribadi, 2019

\section{Amenitas}

Dampak dari kegiatan wisata di Keraton Surakarta belum dirasakan langsung oleh masyarakat setempat. Sehingga daya dukung wisata sekitar belum berkembang di daerah Keraton Surakarta. Dengan kata lain, daya dukung wisata yang tersedia terbatas jenis dan jumlahnya. Meskipun demikian, wisatawan tidak mengeluhkan harga yang ada di Keraton Surakarta (Gambar 3).

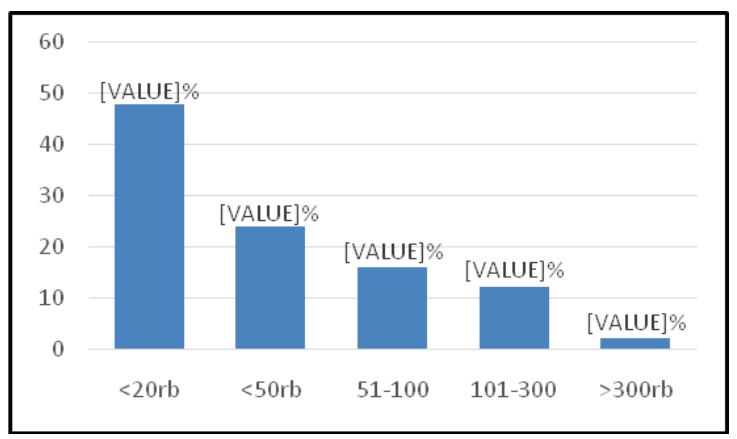

Gambar 3. Pengeluaran Wisatawan Saat Berkunjung di Keraton Surakarta Sumber : Survey Kuesioner Peneliti, 2018.

\begin{abstract}
Aksesibilitas
Akses menuju Keraton Surakarta mudah untuk diakses karena lokasinya yang berdekatan dengan jalur utama Kota Surakarta. Pilihan moda yang tersedia untuk menuju dan berkeliling di Keraton Surakarta beragam serta mampu mewakili kebutuhan masing-masing kelompok wisatawan. Infrastruktur jalan di kompleks Keraton Surakarta sangat baik, sehingga wisatawan dapat dengan mudah mengganti moda transportasi maupun
\end{abstract}


berpindah mengunjungi destinasi wisata di sekitar Keraton Surakarta.

\section{Kelembagaan}

Karena konflik internal yang terus bergulir, kelembagaan di Keraton Surakarta belum berjalan dengan baik. Padahal terdapat daya tarik lain di kawasan Keraton Surakarta yang berpotensi untuk dikunjungi wisatawan. Karena pengelola belum menjalin kerjasama, maka produk dan jasa yang dimiliki masyarakat setempat belum sepenuhnya dapat dipasarkan ke wisatawan. Meskipun demikian, komunitas, pemerintah dan masyarakat setempat mendukung penuh kegiatan wisata di Keraton Surakarta (Gambar 4).

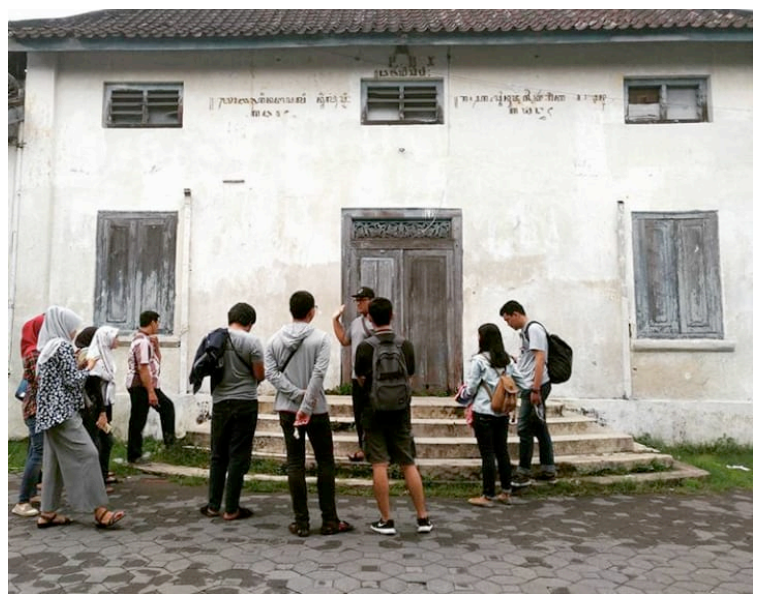

Gambar 4. Kegiatan Salah Satu Komunitas di Kawasan Keraton Surakarta

Sumber : Dokumentasi pribadi, 2018.

Sedangkan pengelola Keraton Yogyakarta melakukan berbagai cara untuk menarik kunjungan wisatawan. Pengelola membangun interaksi dan menjalin keterikatan dengan wisatawan melalui gelaran sajian kebudayaan, memastikan kenyamanan wisatawan dan menjadikan atraksi sebagai hub atau penghubung spasial terhadap kegiatan akomodasi, transportasi dan promosi. Berbagai usaha yang dilakukan pengelola tersebut terbukti berhasil karena jumlah kunjungan wisatawan di Keraton Yogyakarta lebih banyak dibandingkan di Keraton Surakarta.

Konflik internal di badan Keraton Surakarta menyebabkan adanya stagnansi produk wisata. Dukungan pemerintah, masyarakat dan komunitas setempat besar, namun pengelola memiliki fungsi tunggal dalam penyelenggaran dan pengembangan kegiatan wisata di Keraton Surakarta. Pemerintah setempat melalui Dinas Pariwisata, hanya memiliki kewenangan untuk melakukan kegiatan pemasaran. Dengan kata lain, adanya konflik internal menyebabkan pengelola belum dapat menjalankan fungsi kelembagaannya baik secara internal maupun eksternal dalam penyelenggaraan kegiatan wisata.

Saat ini pengelola hanya mengandalkan museum sebagai daya tarik utama. Meskipun demikian, hasil penelitian menunjukkan bahwa kunjungan dan pengalaman wisata yang terbentuk saat mengunjungi Keraton Surakarta baik. Tetapi tetap saja banyak wisatawan yang mengeluhkan sedikitnya pilihan atraksi wisata yang tersedia serta kondisi museum di keraton yang terlihat berdebu dan tidak terawat. Kemudian, wisatawan juga mengeluhkan terbatasnya ragam atraksi wisata Keraton Surakarta. Hasil penelitian juga menunjukkan bahwa kawasan di sekitar Keraton Surakarta belum berkembang menjadi daya dukung wisata yang baik. Hal ini disebabkan belum berkembangnya fasilitas akomodasi dan tidak tersedianya ruang untuk fasilitas amenitas seperti rumah makan, toko cinderamata, fasilitas perbankan dan pusat layanan informasi.

Pengelola belum menggandeng masyarakat dan komunitas setempat, padahal industri rumah tangga masyarakat setempat memiliki daya jual yang baik untuk peningkatan kegiatan wisata di keraton. Lemahnya fungsi pengelola berakibat pada belum adanya intervensi serta integrasi meskipun fisik potensi wisata sudah terpetakan, baik dalam bentuk daya tarik atau produk wisata yang dimiliki masyarakat. Dari penjelasan di atas dapat disimpulkan bahwa prospek peningkatan kualitas komponen wisata di Keraton Surakarta sebagai berikut :

Tabel 1. Kesimpulan Prospek Komponen Pariwisata

\begin{tabular}{|c|c|c|c|}
\hline Komponen & & Keraton Surakarta & Kesimpulan \\
\hline Atraksi & $\begin{array}{l}\text { a) } \\
\text { b) }\end{array}$ & $\begin{array}{l}\text { Keragaman rendah } \\
\text { Terdapat daya tarik lain } \\
\text { yang bisa dikunjungi }\end{array}$ & $\begin{array}{l}\text { Prospek } \\
\text { positif }\end{array}$ \\
\hline Amenitas & $\begin{array}{l}\text { a) } \\
\text { b) } \\
\text { c) }\end{array}$ & $\begin{array}{l}\text { Keragaman rendah } \\
\text { Daya dukung belum } \\
\text { berkembang } \\
\text { Terdapat ndalem-ndalem } \\
\text { yang dapat dimanfaatkan }\end{array}$ & $\begin{array}{l}\text { Prospek } \\
\text { positif }\end{array}$ \\
\hline
\end{tabular}




\begin{tabular}{lllll}
\hline Aksesibilitas & a) & $\begin{array}{l}\text { Kondisi bai } \\
\text { Akses menuju lokasi } \\
\text { mudah }\end{array}$ & $\begin{array}{l}\text { Prospek } \\
\text { positif }\end{array}$ \\
\hline $\begin{array}{llll}\text { Ancillary } \\
\text { services }\end{array}$ & a) & $\begin{array}{l}\text { Kelembagaan } \\
\text { berjalan }\end{array}$ & belum & $\begin{array}{l}\text { Prospek } \\
\text { positif }\end{array}$ \\
& b) & $\begin{array}{l}\text { Dukungan komunitas dan } \\
\text { pemerintah tinggi }\end{array}$ & \\
\hline
\end{tabular}

Sumber: Peneliti, 2018

Berdasarkan Tabel 1, dapat dilihat bahwa Keraton Surakarta memiliki prospek yang besar untuk dikembangkan. Sedangkan Butler (dalam Pearce, 1989) mengatakan bahwa pengembangan suatu destinasi wisata dibagi menjadi 4 tahapan, yaitu :

a. Tahap eksplorasi, di mana tidak banyak terdapat fasilitas, transportasi dan informasi;

b. Tahap pengembangan dan pembangunan, di mana aspek wisata sudah mulai lengkap;

c. Tahap konsolidasi, di mana destinasi berada pada tahapan paling tinggi atau optimal;

d. Tahap stagnansi di mana destinasi berada ada di titik kejenuhan

Merujuk pada model pengembangan oleh Butler tersebut, maka kondisi Keraton Surakarta saat ini berada di tahapan pengembangan dan pembangunan. Daya dukung dan atraksi wisata sudah ada, namun belum cukup untuk menunjang kegiatan wisata di Keraton Surakarta.

Dengan kata lain, komponen wisata di Keraton Surakarta masing-masing memiliki ruang untuk dikembangkan (Tabel 1). Namun karena pariwisata bergantung pada penawaran dan permintaan (demand and supply) dari wisatawan, maka penilaian pasar menjadi hal lain yang harus diperhatikan. Saat ini jumlah wisatawan cukup banyak, namun pertumbuhan jumlah wisatawan cenderung stagnan dengan kunjungan yang didominasi oleh wisatawan nusantara. Selain itu, durasi kunjungan wisatawan sangat singkat, yaitu antara 1-3 jam saja. Meskipun harga-harga dari jasa atau kegiatan wisata yang ditawarkan wajar dan kompetitif.

Prospek peningkatan kualitas komponen wisata di Keraton Surakarta besar mengingat potensi yang dimilikinya. Berikut adalah strategi yang dapat dilakukan untuk meningkatkan kualitas komponen wisata di Keraton Surakarta:
Tabel 2. Usaha Peningkatan

Kualitas Komponen Wisata di Keraton Surakarta

\begin{tabular}{|c|c|c|c|}
\hline Komponen & Kondisi Eksisting & Pengembangan & Output \\
\hline Atraksi & $\begin{array}{l}\text { a. Keragaman } \\
\text { rendah } \\
\text { b. Terdapat daya } \\
\text { tarik lain yang } \\
\text { bisa dikunjungi }\end{array}$ & $\begin{array}{ll}\text { a. } & \text { Peningkatan } \\
& \text { keragaman daya } \\
\text { tarik wisata } \\
\text { b. } & \text { Integrasi daya } \\
\text { tarik wisata }\end{array}$ & $\begin{array}{l}\text { a. Durasi } \\
\text { kunjungan } \\
\text { bertambah } \\
\text { b. Citra } \\
\text { destinasi } \\
\text { meningkat }\end{array}$ \\
\hline Amenitas & $\begin{array}{l}\text { a. Keragaman } \\
\text { rendah } \\
\text { b. Daya dukung } \\
\text { belum } \\
\text { berkembang } \\
\text { c. Terdapat } \\
\text { ndalem-ndalem } \\
\text { yang dapat } \\
\text { dimanfaatkan }\end{array}$ & 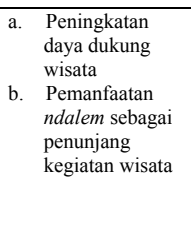 & $\begin{array}{l}\text { a. Ragam } \\
\text { pilihan bagi } \\
\text { wisatawan } \\
\text { b. Dampak } \\
\text { ekonomi } \\
\text { bagi } \\
\text { masyarakat } \\
\text { setempat } \\
\text { c. Pelestarian } \\
\text { bangunan }\end{array}$ \\
\hline Aksesibilitas & $\begin{array}{l}\text { a. Kondisi baik } \\
\text { b. Akses menuju } \\
\text { lokasi mudah }\end{array}$ & $\begin{array}{l}\text { Peningkatan } \\
\text { aksesibilitas }\end{array}$ & $\begin{array}{l}\text { Kemudahan } \\
\text { mobilitas inta } \\
\text { destinasi }\end{array}$ \\
\hline $\begin{array}{l}\text { Ancillary } \\
\text { services }\end{array}$ & $\begin{array}{l}\text { a. Kelembagaan } \\
\text { belum berjalan } \\
\text { b. Dukungan } \\
\text { komunitas dan } \\
\text { pemerintah } \\
\text { tinggi }\end{array}$ & $\begin{array}{l}\text { Peningkatan } \\
\text { sumber daya, } \\
\text { kerjasama dan } \\
\text { dukungan } \\
\text { komunitas }\end{array}$ & $\begin{array}{l}\text { a. Keterikatan } \\
\text { tempat } \\
\text { antara } \\
\text { destinasi } \\
\text { dengan } \\
\text { wisata } \\
\text { b. Keberlanjut } \\
\text { an kegiatan } \\
\text { wisata }\end{array}$ \\
\hline
\end{tabular}

Sumber: Peneliti, 2018

Tabel 2 menunjukkan beberapa strategi untuk meningkatkan kualitas komponen pariwisata di Keraton Surakarta. Dengan adanya integrasi dan penambahan ragam budaya, tentu durasi kunjungan wisatawan akan lebih lama dari sebelumnya. Hal tersebut akan diikuti dengan adanya peningkatan kualitas komponen wisata dan peningkatan potensi jumlah wisatawan yang akan berkunjung. Kemudian, ketika kelembagaan sudah menjalankan fungsi internal dan eksternalnya, maka diproyeksikan jumlsh kunjungan wisatawan akan tumbuh stabil.

Hal tersebut akan terjadi dengan catatan kelembagaan dapat menjaga keberlanjutan kegiatan wisata dengan terus berinovasi melakukan pengembangan produk-produk wisata. Selanjutnya, dengan tumbuhnya berbagai daya dukung wisata, maka karakter wisatawan yang datang ke Keraton Surakarta akan lebih beragam.Keragaman atraksi wisata di Keraton Surakarta akan mempengaruhi lama kunjung wisatawan. Dengan bertambahnya durasi kunjungan wisatawan, maka akan semakin besar pula biaya yang akan dikeluarkan wisatawan saat berkunjung ke Keraton Surakarta. Sehingga, dengan demikian, kegiatan wisata di Keraton Surakarta mampu memberikan dampak yang beragam (multiplier effect)terhadap kondisi sekitar. 


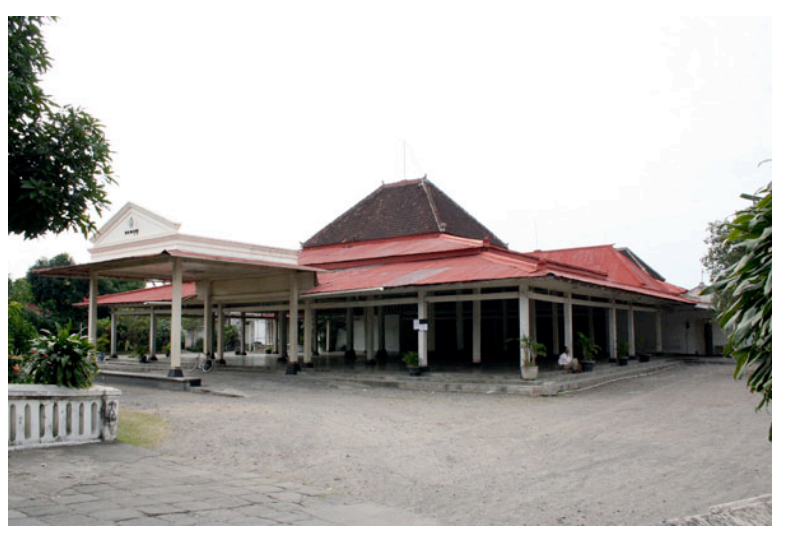

Gambar 5. Ilustrasi Pemanfaatan Ndalem Sebagai Ruang Komunal Sumber: Dokumentasi Pribadi, 2019

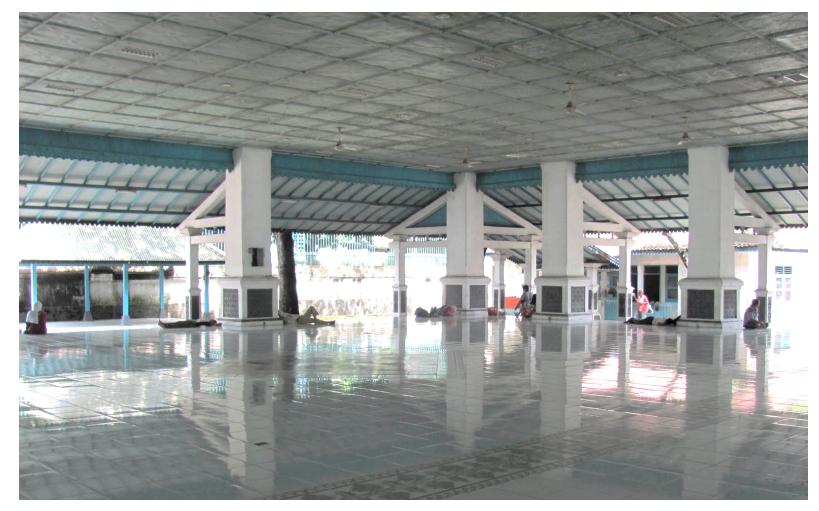

Gambar 6 Ilustrasi Ruang

Pameran Foto di Kompleks

Sitihinggil

Sumber: Ilustrasi Peneliti, 2019 kesinambungan kegiatan wisata. Konflik internal yang terus bergulir mengakibatkan adanya stagnansi produk dan tidak berkembangnya kawasan sekitar Keraton Surakarta sebagai daya dukung wisata.

Ketidakhadiran pengelola dalam penyelenggaraan kegiatan wisata di Keraton Surakarta menyebabkan tidak adanya usaha atau kebijakan yang dapat meningkatkan kualitas kegiatan wisata di Keraton Surakarta. Padahal, Keraton Surakarta memiliki begitu banyak peluang dan potensi yang dapat dikembangkan. Guna meningkatkan kualitas komponen pariwisata di Keraton Surakarta, pengelola perlu meredam konflik dan menjalin kerjasama yang berkelanjutan antara pengelola, pemerintah, komunitas dan masyarakat setempat.

\section{SIMPULAN \\ Simpulan}

Kualitas komponen pariwisata di Keraton Surakarta kurang karena tidak didukung dengan keragaman atraksi, keberadaan daya dukung wisata dan sistem kelembagaan yang baik. Pengelola hanya mengandalkan museum sebagai daya tarik. Padahal selain terdapat berbagai macam potensi wisata yang dapat dikembangkan, akses menuju ke Keraton Surakarta cukup mudah.

Adanya dukungan dari komunitas dan pemerintah setempat ternyata belum mampu untuk meningkatkan kualitas komponen pariwisata di Keraton Surakarta. Hal tersebut dikarenakan pengelola memiliki kewenangan tunggal dalam mengembangkan dan menjaga 


\section{Kepustakaan}

Black, J., \& Conroy, M. 1977. Accessibility Measures and the Social Evaluation of Urban Structure. Environment and Planning A: Economy and Space, Vol 9, No 9, $\mathrm{p}:$ 1013-1031.

Cakici, A Celil., Harman, Serhat. 2007. Importance of Destination Attributes Affecting Destination Choice of Turkish Birdwatchers. Journal of Commerce \& Tourism Education Faculty, No 1, p : 131-145.

Cooper, Christopher P., 2005. Tourism : Principles and Practice ( $3 r d$ ed). Financial Times Prentice Hall. England : Harlow.

Geng-Qing Chi, Christina., et al. 2018. Examining destination personality: Its antecedents and outcomes. Journal of Destination Marketing and Management 9, p:149-159.

KBBI, 2016. Kamus Besar Bahasa Indonesia (KBBI). [Online] Available at: http://kbbi.web.id/pusat, diakses 6 Januari 2019.

Krugman, Paul R. dan Maurice Obstfeld. 2005. Ekonomi Internasional Teori dan Kebijakan, Edisi 5 Jilid 2. Jakarta : Gramedia.

Maryani, E. 1991:11. Pengantar Geografi Pariwisata. Bandung : IKIP.

Mason, Peter. 2000. Tourism Impacts, Planning and Management. New York: Routledge.

Sun Tung, VW., Brent Ritchie, JR. 2011. Exploring the essence of memorable tourism experiences. Annals of Tourism Research, Vol 38, No 4, p : 367-1386.

Yoeti, Oka Antara. 1985. Pengantar Ilmu Pariwisata. Bandung : Angkasa. 